\title{
CLOSTRIDIUM BOTULINUM TOXIN A SIGNIFICANTLY INHIBITS UTERINE CONTRACTIONS IN RATS UNDERGOING MIFEPRISTONE-INDUCED PRETERM LABOR
}

\author{
Hang-Yong Jang, MD, Kyung-Mi Lee, MD, Young-Sin Park, MD, Myung-Jin Moon, MD, Won-Bo Hahn, MD, \\ Eun-Hee Ahn, MD \\ Department of Obstetrics and Gynecology, Bundang CHA General Hospital, CHA University College of Medicine. Seongnam, Korea
}

\section{Objective}

We investigated the in vivo tocolytic effect of Clostridium botulinum toxin A (BoNT/A) on mifepristone-induced preterm labor in rats.

\section{Methods}

On day 17 of gestation, an incision was made to expose the uterus, and BoNT/A (normal saline or 20 units) was injected into the uterine horns. On day 18, mifepristone was used to induce uterine contractions. Electrical activity of uterine contractions was measured via electromyography on day 19.

Results

In rats treated with 20 units of BoNT/A, the amplitude of uterine contractions was significantly decreased by $45.2 \pm 18.4$ $(P<0.05)$ from baseline, respectively. The total duration of uterine contractions was significantly decreased by $51.7 \pm 7.9(P<0.01)$, respectively. The frequency of contraction bursts after treatment with 20 units of BoNT/A was decreased by $5.6 \pm 16.3$ from the baseline $(P=0.4)$.

\section{Conclusion}

In rats undergoing mifepristone-induced preterm labor, BoNT/A significantly inhibited uterine contractility. The decrease in uterine activity was mainly caused by a decline in the duration and intensity rather than frequency of uterine contractions.

Keywords: Clostridium botulinum toxin A; Tocolytics; Preterm labor; Mifepristone; Rat

Preterm labor is defined as the presence of regular uterine contractions with progressive cervical changes before 37 completed weeks of pregnancy. Spontaneous preterm labor accounts for $40 \%$ to $50 \%$ of all preterm births [1]. An estimated 13 million babies $(-10 \%$ of all births) are born preterm each year worldwide, and approximately 1 million of all newborn deaths are due to preterm birth [2].

At present, typical uterine contraction inhibitors (e.g., betamimetics, magnesium sulfate, calcium channel blockers, oxytocin receptor antagonists, and prostaglandin inhibitors) have achieved limited success for short-term management of preterm labor. Although tocolytic agents were superior to placebo at delaying delivery for at least 7 days in a meta-analytic study, none was statistically more effective than placebo at delaying delivery to 37 weeks gestation or at reducing neonatal mortality and morbidity [3]. Women receiving tocolytics for preterm labor require monitoring and inten-

Received: 2012.4.7. Revised: 2012.6.29. Accepted: 2012.7.3. Corresponding author: Eun-Hee Ahn, MD, PhD

Department of Obstetrics and Gynecology, Bundang CHA General Hospital, CHA University College of Medicine, 82 Gumi-ro 173beon-gil, Bundang-gu, Seongnam 463-707, Korea Tel: +82-31-780-5000 Fax: +82-32-714-3401

E-mail: bestob@cha.ac.kr

This is an Open Access article distributed under the terms of the Creative Commons Attribution Non-Commercial License (http://creativecommons.org/licenses/ by-nc/3.0/) which permits unrestricted non-commercial use, distribution, and reproduction in any medium, provided the original work is properly cited.

Copyright $\odot$ 2012. Korean Society of Obstetrics and Gynecology 
sive support for serious side effects that may affect both the mother and fetus, including chest pain, dyspnea, palpitations, tremors, headaches, hyperglycemia, hypokalemia, and fetal tachycardia [4]. Despite the development of modern neonatal care, infants born prior to 28 weeks of gestation, in whom fetal lung development is premature, exhibit high mortality and morbidity rates [5]. Extending pregnancy by a few more weeks can make a huge difference in neonatal outcomes. Therefore, a new treatment approach that results in long-term prevention of premature uterine contraction is required to lower neonate mortality.

Clostridium botulinum toxin A (BoNT/A) blocks the release of the neurotransmitter acetylcholine $(A C h)$ from presynaptic nerve endings [6]. While it has been primarily shown to affect skeletal muscles, there is much evidence showing that BoNT/A also affects smooth muscles, including the gastrointestinal [7] and detrusor muscle [8]. Recently, two reports supported its effects on the myometrium. In 2003, Garza et al. [9] demonstrated that BoNT/ A inhibits the spontaneous uterine activity of pregnant rat myometrium in vitro. In 2009, Burd et al. [10] reported that BoNT/ A suppresses oxytocin-induced contractions of pregnant human myometrium in vitro. Currently, BoNT/A is approved by the Food and Drug Administration (FDA) for several clinical indications, including strabismus, blepharospasm, facial nerve VII disorders, cervical dystonia, primary axillary hyperhidrosis, and chronic migraine headaches, and as a cosmetic treatment for glabellar lines. Other uses of BoNT/A that are successful treatments not yet approved by FDA include treatment of achalasia, lower urinary tract dysfunction, chronic anal fissures, various spastic disorders, neuropathies, wound healing, and various cosmetic indications.

The purpose of this study was to evaluate the tocolytic effect of BoNT/A on mifepristone-induced preterm labor in pregnant rats by determining changes in electromyography (EMG) activity of uterine contractility in vivo.

\section{Materials and Methods}

\section{Animals}

Fourteen primiparous Sprague-Dawley rats of approximately 10 weeks of age were supplied by Nara Biotech (Seoul, Korea). The average body weight of the rats was $309 \mathrm{~g}$ (range, 245-354 g). Determination of pregnancy was made by the observation of a vaginal plug. Plug observation date was considered to be day 1 of gestation. The pregnant rats were caged singly until the animals arrived in our laboratory on day 16 of gestation. In our labora- tory, two rats were housed together in a standard animal cage $(420 \times 270 \times 180 \mathrm{~mm})$. Rats had free access to water and pellets, were housed in a light-controlled room with 13 hours of light (7 AM-8 PM) and 11 hours of darkness, and were maintained at a temperature of $22^{\circ} \mathrm{C}$ to $24^{\circ} \mathrm{C}$. The animal experimentation described in this study was approved by the CHA University School of Medicine Institutional Animal Care and Use Committee.

\section{Anesthesia}

The animals were anesthetized for both surgical procedures and EMG recordings. General anesthesia was induced by intramuscular injection of a mixture of $0.06 \mathrm{~mL}$ tiletamine plus zolazepam (Zoletil 50, Virbac, Carros, France) and $0.06 \mathrm{~mL}$ xylazine (Rompun, Bayer Korea, Seoul, Korea). If a surgical procedure was prolonged or induction of anesthesia was insufficient, a subsequent intramuscular injection was given at one-half the original dose.

\section{Drugs and treatments}

A total of fourteen rats were randomly assigned into two groups. Seven rats were assigned as a sham-operated group (group A), which were treated with normal saline. Seven rats were assigned as an experimental group (group B), which were administered BoNT/A at dose of $20 \mathrm{U}$. On day 17 of gestation, both uterine horns were exposed through a midline abdominal incision under sterile conditions in all animals. Each rat in the sham-operated group was administered a total volume of $1.2 \mathrm{~mL}$ of normal saline on both uterine horns $(0.6 \mathrm{~mL}$ of normal saline on each uterine horn), regardless of differences in uterine horn size. Experimental group was administered a total volume of $1.2 \mathrm{~mL}$ of $20 \mathrm{U}$ BoNT/

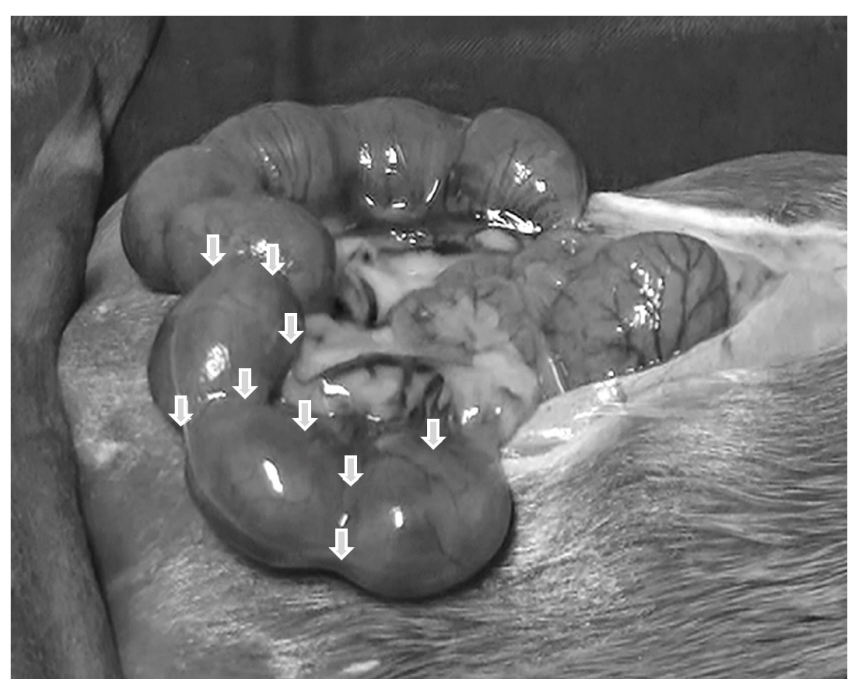

Fig. 1. Injection sites (white arrows) on the left side of the uterine horn. 
A (Neuronox, Medy-Tox, Seoul, Korea). Injections were made on the lower portion of each uterine horn, in an area where a large amount of the uterine myometrium is located, and the mesometrium is attached (Fig. 1). Injections were also made in an area between the bulging region of the gestational lumen of both sides and the upper middle portion of the uterine horn. Direct injections into the gestational sac were avoided. Special needles (Johns screw needles, Woorhi Medical, Seoul, Korea), which offer control of needle length from 0 to $7 \mathrm{~mm}$, were used at a needle length of $1 \mathrm{~mm}$. After injections on the uterus, the abdominal wall and skin were closed with continuous running sutures of \#3-0 nylon. Preterm labor was induced with mifepristone (RU-486, Ascent Scientific, (ambridge, UK) in all animals [11]. On day 18 of gestation, a single subcutaneous injection of mifepristone (3 $\mathrm{mg}$ suspended in $0.2 \mathrm{~mL}$ olive oil) was made in the rat buttocks, which resulted in preterm labor within 24 hours.

\section{EMG recordings}

A Medelec Synergy N2 machine (Oxford Instruments, Oxfordshire, UK) was used to record the EMG activity of uterine contractility. EMG activity was recorded on day 19 (approximately 23 to 24 hours after mifepristone injection). Uterine EMG activity was recorded from the abdominal surface. A number of animal and human studies have shown transabdominal surface measurements of uterine EMG activity to correlate well with intrauterine pressure [12]. All animals were anesthetized for EMG recordings. Abdominal hair was removed with $80 \%$ thioglycolic acid cream. A pair of disposable surface pickup electrodes was placed approximately 10 to $15 \mathrm{~mm}$ apart on the abdominal wall, overlaying the uterine horn. A reference electrode was placed near the chest area to reduce artifacts caused by movements of the chest wall. The band-pass filter was set from 0.5 to $50 \mathrm{~Hz}$. At the end of the EMG recordings (24 hours after mifepristone injection), the number of premature deliveries and pups delivered by each rat were counted, and all rats were euthanized by cervical dislocation under anesthesia.

\section{Quantification of data and statistical analyses}

All EMG data were recorded and visually analyzed using Medelec Synergy software (ver. 11.1, Oxford Instruments). The duration and latency time (in milliseconds) were analyzed using a vertical cursor. The peak-to-peak amplitude $(\mu \mathrm{V})$ of each burst was evaluated using a horizontal cursor. The onset of a burst was defined by the amplitude progressively rising to at least twice the baseline electrical activity for a period of at least 5 seconds. All the resultant data is expressed as the mean \pm standard error of the mean (SEM). Mean percent change from baseline is expressed as the mean percent change \pm SEM $\%$ (SEM/mean $\times 100)$. Statistical comparisons of groups are based on the Wilcoxon rank sum test performed using SAS Enterprise Guide software (ver. 4.1, SAS Institute, Cary, NC, USA). A $P$-value less than 0.05 indicates a statistically significant difference.

\section{Results}

Five of seven rats $(71.4 \%)$ in the sham-operated group delivered seven pups within 24 hours after treatment with $3 \mathrm{mg}$ mifepristone, whereas two of seven (28.5\%) rats in the experimental group delivered two pups prematurely. Uterine EMG activity was characterized by regular, higher amplitude, and longer duration bursts of action potentials in the sham-operated group compared to animals treated with BoNT/A (Fig. 2A). The animals in groups $B$ showed notably reduced uterine electromyographic activity compared to the sham-operated group in terms of decreased amplitude and duration of uterine contractions (Fig. 2B). Increas-
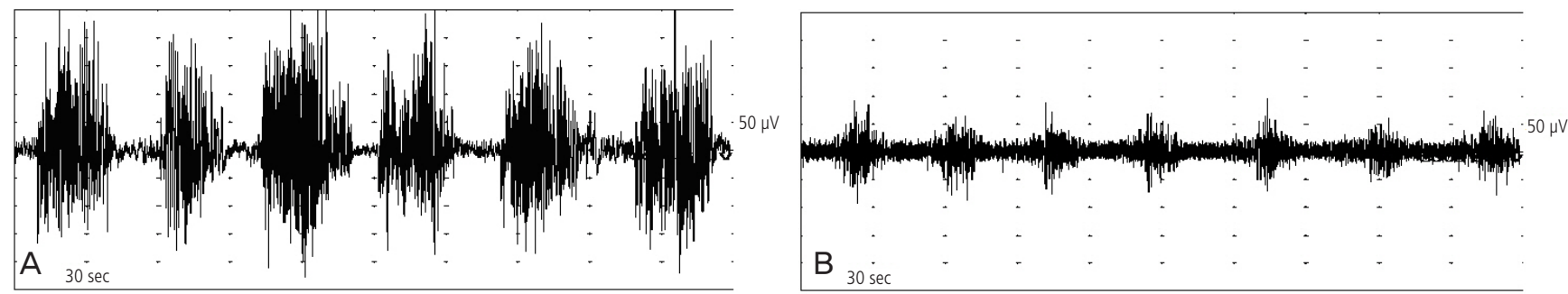

Fig. 2. Raw data samples of electromyography (EMG) recordings within a 5-min period from the abdominal surfaces of pregnant rats on day 19 of gestation. (A) An EMG recording from a rat in the sham-operated group (group A). Uterine EMG activity was characterized by regular, higher amplitude, and longer duration bursts of action potentials compared to animals treated with BoNT/A. (B) EMG recordings from a rat in the 20-U (group B) group, respectively. Note that the intensity and duration of uterine electrical activity were notably decreased in these groups compared with the sham-operated group. 

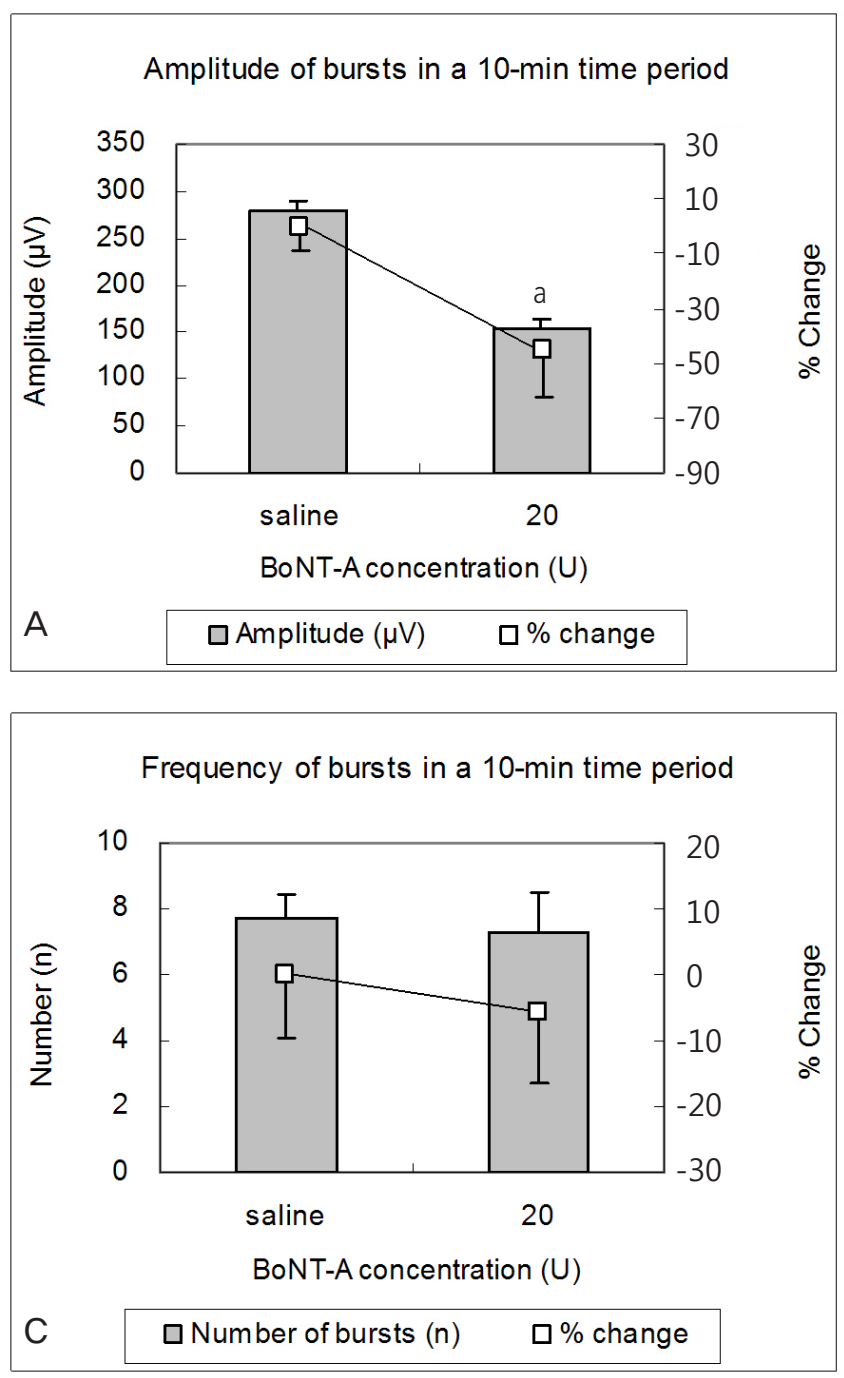

ing the concentration to $20 \mathrm{U}$ of BoNT/A significantly decreased the amplitude of bursts by $45.2 \% \pm 18.4 \%(P<0.05)$ compared to that of the sham-operated group (Fig. 3A). The total duration of uterine contractions for these groups was significantly decreased by $51.7 \% \pm 7.9 \%(P<0.01)$, respectively (Fig. 3B). The frequency of uterine contractions for animals in group $B$ was decreased by $5.6 \% \pm 16.3 \%(P=0.4)$ compared to the sham-operated group (Fig. 3C).

\section{Discussion}

To our knowledge, this is the first in vivo study showing that BoNT/A not only inhibits uterine contractions, but also delays rat delivery of pups in mifepristone-induced preterm labor. The

\section{Duration of bursts in a 10-min time period}

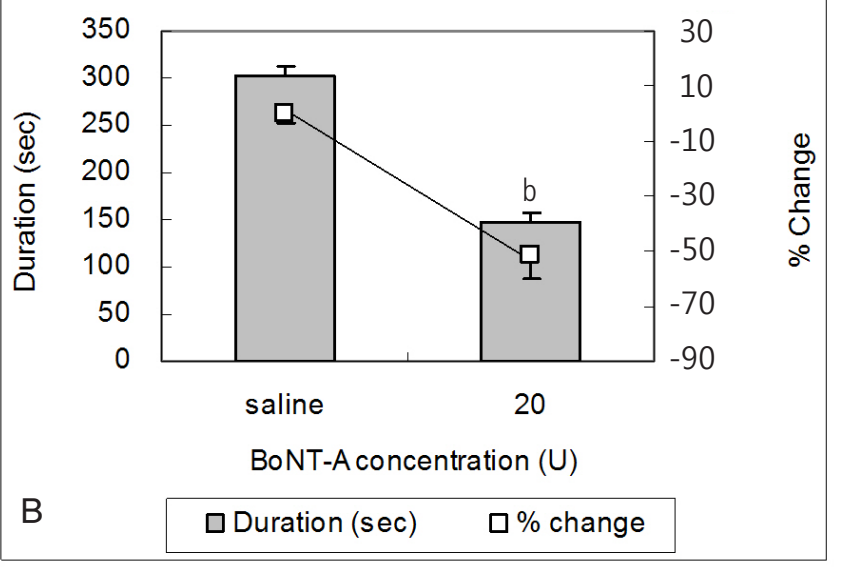

Fig. 3. The relationship between the concentration of BoNT/A and its effects (amplitude, duration of bursts, and frequency) within a 10-min period on uterine myometrium as evaluated by abdominal surface electromyography. Results are marked with one asterisk a) if $P<0.05$ and two b)if $P<0.01$. U, units of BoNT/A injected to both uterine horns. (A) Amplitude of bursts. Increasing the concentration to $20 \mathrm{U}$ of BoNT/A significantly decreased the amplitude of bursts by $45.2 \% \pm 18.4 \%(P<0.05)$ compared to that of the sham-operated group. (B) Duration of bursts. Increasing the concentrations to $20 \mathrm{U}$ of BoNT/A significantly shortened the duration of bursts by $51.6 \% \pm 7.9 \%(P<0.01)$, respectively. (C) Frequency of bursts. Although increasing the concentration to $20 \mathrm{U}$ of BoNT/A decreased the number of bursts by $5.6 \% \pm 16.3 \%$ from baseline, this decrease was not statistically significant $(P=0.4)$. BoNT/A, Clostridium botulinum toxin A.

decrease in uterine activity was mainly caused by a decline in the duration and amplitude, rather than a decline in the frequency, of uterine contractions. At $20 \mathrm{U}$ of BoNT/A, the decrease in uterine activity was prominent in the electromyographic results. Although the frequency of uterine contractions was not statistically significant $(P=0.399)$ in this experiment. A significant decrease in the frequency of uterine contractions may be expected at higher doses of BoNT/A beyond 20 units, as shown by Garza et al. [9], but this would eventually reach the lethal/toxic threshold of BoNT/A (IM LD50, 114.1 111.5 U/kg; unpublished raw data, Medy-Tox, Seoul, Korea) in vivo. Based on visual observations during EMG recording, the experimental animals treated with BoNT/A showed neither changes in movement or behavior nor excessive vaginal bleeding, except for a small amount of brownish discharge or blood at the lips of the vulva, compared to the sham-operated animals during 


\section{KOREAN JOURNAL OF OBSTETRICS \& GYNECOLOGY}

Hang-Yong Jang, et al. Tocolytic effect of botulinum toxin type $\mathrm{A}$

labor.

BoNT/A is labeled as a pregnancy risk category $C$ drug by the FDA [6], which means that well-controlled human studies are lacking and safety of this drug for use during pregnancy has not been established. Therefore, we do not know whether its use constitutes a chance of fetal harm. In one report in which 16 pregnant women were treated with BoNT/A, no adverse effects on the fetus or mother were observed, except one mother, with a prior history of spontaneous abortions suffered a miscarriage [13]. Uncomplicated full-term pregnancies of four women, who received regular Botox treatments for cervical dystonia, have also been reported [14]. Furthermore, to date, no adverse effects of BoNT/A to either the mother or fetus during pregnancy have been reported. The molecular weight of BoNT is $150 \mathrm{kDa}$; therefore, it is unlikely that BoNT passes through the placental membrane [13]. However, it is unknown whether an active transport mechanism exists, so potential effects on the fetus should not be ignored.

No clinical trials for Clostridium botulinum toxin type A for inhibition of uterine contractions during preterm labor have been conducted to date. Therefore, we do not know the optimal dose of BoNT/A on the human uterus for prevention of preterm labor. In a meta-analysis of patients with overactive bladder syndrome treated with BoNT/A, lower doses of botulinum toxin (100 U) appeared to elicit beneficial effects; however, larger doses (300 U) were found to be more effective and longer lasting but had more side effects, such as urinary retention and urinary tract infection [15]. If BoNT/A were to be used during pregnancy in humans, lower doses $(<100 \mathrm{U})$ would be recommended, because higher doses may cause unwanted side effects, such as uterine atony and unnecessarily persistent inhibition of uterine contractions. Administration of lower doses of botulinum toxin would provide ongoing suppression of uterine contractions to maintain pregnancy with potentially fewer side effects. In addition, if stronger suppression of uterine contractions is necessary to prevent preterm labor, concomitant administration of a current tocolytic agent, such as betamimetics, and BoNT/A may yield a stronger synergistic inhibition of uterine contractions. In regard to the method of administration, the use of ultrasonography with color-flow Doppler as a guide allows the entrance of a needle (18 gauge spinal needle) and delivery of BoNT/A into the muscular layers of the fundus, avoiding the vascular structures of the uterus, as the mechanical activity of the uterus is initiated in the fundus during normal labor [16].

Clostridium botulinum neurotoxin consists of a zinc-dependent protease light chain $(50 \mathrm{kDa})$ and a membrane-binding heavy chain (100 kDa), which are joined by a disulfide bond [6]. There are seven BoNT serotypes (A, B, C1, D, E, F, and G), defined by differences in the light chains and result in different muscle-affecting properties. BoNT/A and BoNT/E cleave a synaptosome-associated protein of $25 \mathrm{kDa}$ (SNAP-25), while BoNT/B, /D, /F, and /G cleave vesicle-associated membrane protein or synaptobrevin [6]. BoNT/ C1 is reported to cleave both syntaxin and SNAP-25, which are essential for vesicle fusion at presynaptic terminals, due to their ability to form a SNARE complex; their cleavage blocks membrane fusion of presynaptic vesicles containing ACh $[6,17]$. Consequent$l y$, inhibition of such neurotransmitter release from presynaptic neurons results in muscle paralysis. Until now, the mechanisms explaining BoNT/A inhibition of uterine myometrial contractions have been unknown. Unlike skeletal muscles, uterine smooth muscles are affected by $\alpha$ - and $\beta$-adrenergic receptors [18]. There is also evidence showing that uterine smooth muscle is affected by cholinergic nerves that play important roles in stimulating contraction of myometrium and vasculature $[19,20]$. Since botulinum toxin blocks cholinergic transmission by inhibiting ACh release, we may postulate that the effect of BoNT/A on cholinergic neurons innervating the uterus is likely the cause of reduced uterine contractions in pregnant rats. Such a view accords well with indirect studies of smooth muscles such as the sphincter of Oddi [21] and the pyloric sphincter [22]. In regards to the pyloric sphincter study, it has been suggested that higher concentrations of botulinum toxin may have a direct inhibitory effect on smooth muscle contractility by acting on smooth muscle muscarinic receptors [22]. Such experimental observations were further supported by a study of the immunohistochemical expression of muscarinic receptors in patients of detrusor overactivity treated with BoNT/A compared with controls. Specifically, it was shown that these patients not only had an improvement in urgency after treatment, but also a significant decline in $\mathrm{M}_{1}$ and $\mathrm{M}_{3}$ receptor immunoreactivity [23]. Interestingly, studies of the pharmacological characteristics of muscarinic receptors in rat and mouse isolated myometrium using selective muscarinic antagonists indicated that the muscarinic $\mathrm{M}_{3}$ receptors are a major mediator of uterine contraction $[24,25]$. Further exploration is needed to determine the correlation of expression levels of these receptors with BoNT/A in the uterus during pregnancy. These efforts will guide us to gain a better understanding and preventing of preterm labor.

\section{Acknowledgements}

Hye-Young Jung, MS, Department of Education, CHA University 
College of Medicine, helped with the statistical analyses. This study was partially supported by grant MT-NCS-002 from Neuronox, Medy-Tox Inc., Korea.

\section{References}

1. Wen SW, Smith G, Yang Q, Walker M. Epidemiology of preterm birth and neonatal outcome. Semin Fetal Neonatal Med 2004;9:429-35.

2. Beck S, Wojdyla D, Say L, Betran AP, Merialdi M, Requejo JH, et al. The worldwide incidence of preterm birth: a systematic review of maternal mortality and morbidity. Bull World Health Organ 2010;88:31-8.

3. Haas DM, Imperiale TF, Kirkpatrick PR, Klein RW, Zollinger TW, Golichowski AM. Tocolytic therapy: a meta-analysis and decision analysis. Obstet Gynecol 2009;113:585-94.

4. Anotayanonth S, Subhedar NV, Garner P, Neilson JP, Harigopal $S$. Betamimetics for inhibiting preterm labour. Cochrane Database Syst Rev 2004;(4):CD004352.

5. Jakuskiene R, Vollmer B, Saferis V, Daugeliene D. Neonatal outcomes of very preterm infants admitted to a tertiary center in Lithuania between the years 2003 and 2005. Eur J Pediatr 2011;170:1293-303.

6. Huang W, Foster JA, Rogachefsky AS. Pharmacology of botulinum toxin. J Am Acad Dermatol 2000;43:249-59.

7. Brisinda G, Civello IM, Albanese A, Maria G. Gastrointestinal smooth muscles and sphincters spasms: treatment with botulinum neurotoxin. Curr Med Chem 2003;10:603-23.

8. Karsenty G, Corcos J, Schurch B, Ruffion A, Chartier-Kastler E. Pharmacological treatment of neurogenic detrusor hyperactivity: intradetrusor botulinum toxin A injections. Prog Urol 2007; 17:568-75.

9. Garza JJ, Downard CD, Clayton N, Maher TJ, Fauza DO. Clostridium botulinum toxin inhibits myometrial activity in vitro: possible application on the prevention of preterm labor after fetal surgery. J Pediatr Surg 2003;38:511-3.

10. Burd ID, Ness A, DiMuzio P, Ren GY, Tulenko TN. Clostridium botulinum toxin $A$ inhibits contractility in pregnant human myometrium in vitro. Reprod Sci 009;16:1001-4.

11. Doret M, Bukowski R, Longo M, Maul H, Maner WL, Garfield $R E$, et al. Uterine electromyography characteristics for early diagnosis of mifepristone-induced preterm labor. Obstet Gynecol 2005;105:822-30.

12. Buhimschi C, Boyle MB, Saade GR, Garfield RE. Uterine activity during pregnancy and labor assessed by simultaneous recordings from the myometrium and abdominal surface in the rat. Am J Obstet Gynecol 1998;178:811-22.

13. Morgan JC, lyer SS, Moser ET, Singer C, Sethi KD. Botulinum toxin A during pregnancy: a survey of treating physicians. J Neurol Neurosurg Psychiatry 2006;77:117-9.

14. Newman WJ, Davis TL, Padaliya BB, Covington CD, Gill CE, Abramovitch Al, et al. Botulinum toxin type A therapy during pregnancy. Mov Disord 2004;19:1384-5.

15. Duthie JB, Vincent M, Herbison GP, Wilson DI, Wilson D. Botulinum toxin injections for adults with overactive bladder syndrome. Cochrane Database Syst Rev 2011;(12):CD005493.

16. Buhimschi CS, Buhimschi IA, Malinow AM, Saade GR, Garfield RE, Weiner CP. The forces of labour. Fetal Matern Med Rev 2003;14:273-307.

17. Jin R, Sikorra S, Stegmann CM, Pich A, Binz T, Brunger AT. Structural and biochemical studies of botulinum neurotoxin serotype C1 light chain protease: implications for dual substrate specificity. Biochemistry 2007;46:10685-93.

18. Liu YL, Nwosu UC, Rice PJ. Relaxation of isolated human myometrial muscle by beta2-adrenergic receptors but not beta1adrenergic receptors. Am J Obstet Gynecol 1998;179:895-8.

19. Papka RE, Traurig HH, Schemann M, Collins J, Copelin T, Wilson $\mathrm{K}$. Cholinergic neurons of the pelvic autonomic ganglia and uterus of the female rat: distribution of axons and presence of muscarinic receptors. Cell Tissue Res 1999;296:293-305.

20. Dittrich R, Mueller A, Oppelt PG, Hoffmann I, Beckmann MW, Maltaris T. Differences in muscarinic-receptor agonist-, oxytocin-, and prostaglandin-induced uterine contractions. Fertil Steril 2009;92:1694-700.

21. Sand J, Nordback I, Arvola P, Pörsti I, Kalloo A, Pasricha P. Effects of botulinum toxin $A$ on the sphincter of Oddi: an in vivo and in vitro study. Gut 1998;42:507-10.

22. James AN, Ryan JP, Parkman HP. Inhibitory effects of botulinum toxin on pyloric and antral smooth muscle. Am J Physiol Gastrointest Liver Physiol 2003;285:G291-7.

23. Datta SN, Roosen A, Pullen A, Popat R, Rosenbaum TP, Elneil $S$, et al. Immunohistochemical expression of muscarinic receptors in the urothelium and suburothelium of neurogenic and idiopathic overactive human bladders, and changes with botulinum neurotoxin administration. J Urol 2010;184:2578-85.

24. Choppin A, Stepan GJ, Loury DN, Watson N, Eglen RM. Characterization of the muscarinic receptor in isolated uterus of sham operated and ovariectomized rats. Br J Pharmacol 1999;127:1551-8. 


\section{KOREAN JOURNAL OF OBSTETRICS \& GYNECOLOGY}

Hang-Yong Jang, et al. Tocolytic effect of botulinum toxin type A

25. Kitazawa T, Hirama R, Masunaga K, Nakamura T, Asakawa K, Cao J, et al. Muscarinic receptor subtypes involved in carba- chol-induced contraction of mouse uterine smooth muscle. Naunyn Schmiedebergs Arch Pharmacol 2008;377:503-13.

\section{클로스트리디움 보툴리눔 독소 A형은 미페프리스톤으로 유발된 조기진통 쥐 모델에서 자궁수축을 현저하게 감소시킨다}

차의과학대학교 분당차병원 산부인과

장항용, 이경미, 박영신, 문명진, 한원보, 안은희

\section{목적}

우리는 클로스트리디움 보툴리눔 독소 A형(BoNT/A)이 미페프리스톤으로 유발된 조기진통 쥐 모델에 대해 자궁수축억제 효과가 있는지 in vivo 연구를 실시하였다.

\section{연구방법}

임신 17일, 개복 후 자궁 양측 뿔에 식염수 또는 20 유니트의 BoNT/A를 투여하였다. 임신 18일, 미페프리스톤을 근주하여 자궁의 조기진 통을 유발시켰다. 임신 19일, 근전도검사기를 통하여 자궁수축 활동을 측정하였다.

결과

BoNT/A 20 유니트를 투여한 군은 자궁수축 강도가 BoNT/A를 투여하지 않은 군에 비해 45.2\% ( $P<0.05)$ 로 유의하게 감소하였으며, 자궁 수축 기간은 $51.6 \%(P<0.01)$ 로 유의하게 감소하였다. 하지만 자궁수축 빈도에 대한 감소는 $5.6 \%(P=0.4)$ 로 유의하게 감소는 없었다.

결론

미페프리스톤으로 유발된 조기진통 쥐 모델에서 BoNT/A는 자궁의 수축력을 유의하게 감소시켰다. 자궁수축의 감소는 자궁수축 빈도에 대한 억제효과보다는 자궁수축의 기간 및 강도의 억제효과가 유의했다.

중심단어: 클로스트리디움 보툴리눔 독소 A형, 조기진통억제제, 조기진통, 미페프리스톤, 쥐 